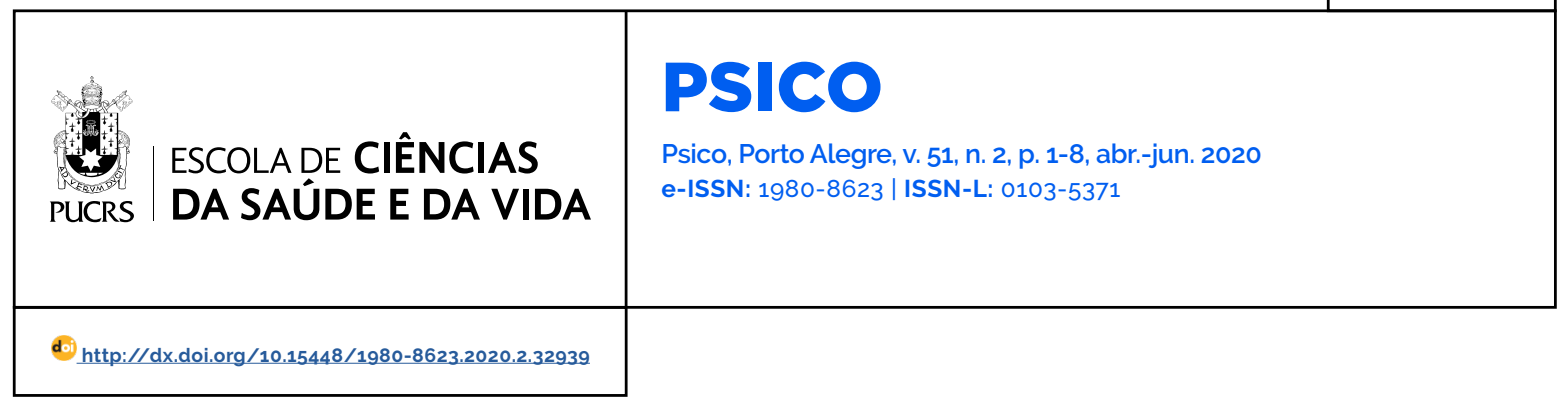

ARTIGO

\title{
Self-compassion in religious practitioners: criterion validity evidence for the Self-Compassion Scale - Brazil
}

\author{
Autocompaixão em praticantes religiosos: evivência de validade de critério para a \\ Escala de Autocompaixão - Brasil \\ Auto-compasión en practicantes religiosos: evidencia de validad de criterio para la \\ Escala de Auto-Compasión - Brasil
}

\section{Luciana Karine de \\ Souza ${ }^{1}$ \\ orcid.org/0000-0001-9641-6163 \\ lukarides@gmail.com}

Caroline Tozzi Reppold2 orcid.org/0000-0002-0236-2553 carolinereppold@yahoo.com.br

\section{Inajá Tavares1}

orcid.org/0000-0002-1131-4879 innatavares@gmail.com

\section{Claudio Simon Hutz1}

orcid.org/0000-0002-3252-7339

claudio.hutz@gmail.com

Recebido em: 7 jan. 2019 Aprovado em: 26 nov. 2019. Publicado em: $x x$ xxx. 2020.

\section{(c) (1)}

Artigo está licenciado sob forma de uma licença Creative Commons Atribuicão 4.0 Internacional.
Abstract: The construct of self-compassion is based on Buddhist's teachings on compassion towards oneself. This study provides criterion validity evidence for the Self-Compassion Scale - Brazil. A comparison on self-compassion in Buddhist and Catholic practitioners may contribute to support the Brazilian version of the scale, as well as shed light into religious differences on the matter. Participated in the study 59 Catholics and 59 Buddhists, all self-declared a religious practitioner. We administered a socio-demographic questionnaire and the Self-Compassion Scale - Brazil. Buddhist practitioners presented significantly higher score in self-compassion $(M=4.45, S D=.51)$ than Catholic practitioners $(M=2.98, S D=.63)$ : $t(116)$ $=13.78, p<.001(d=2.56)$. In addition, there was a significant positive correlation between frequency of religious practice and self-compassion $(r=.39, p=.003)$. Future studies may investigate the relationship between self-compassion and neo-Pentecostal practitioners, which has been increasing in number in Brazil.

Keywords: self-compassion; religious practice; validity evidence; psychological assessment; sca

Resumo: O construto de autocompaixão está baseado em ensinamentos budistas sobre a compaixão direcionada a si. Este estudo fornece evidência de validade de critério para a Escala de Autocompaixão - Brasil. Uma comparação da autocompaixão em praticantes budistas e católicos contribui para apoiar a versão brasileira da escala, bem como sobre diferenças religiosas associadas ao tema. Participaram 59 católicos e 59 budistas, todos autodeclarados como praticantes de sua religião. Foi administrado um questionário sociodemográfico e a Escala de Autocompaixão - Brasil. Os praticantes budistas apresentaram escore significativamente maior em autocompaixão $(M=4.45, S D=.51)$ do que os católicos ( $M$ $=2.98, S D=.63): t(116)=13.78, p<.001(d=2.56)$. Ademais, encontrou-se correlação positiva significativa entre frequência da prática religiosa e autocompaixão $(r=$ .39, $p=.003$ ). Futuros estudos podem investigar a relação entre autocompaixão $e$ praticantes de religiões neopentecostais, que vêm crescendo em número no Brasil. Palavras-chave: autocompaixão; prática religiosa; evidência de validade: avaliação psicológica; escala

Resumen: El constructo de auto-compasión está basado en enseñanzas budistas sobre compasión direccionada a uno mismo. Este estudio tiene como finalidad aportar evidencia de validad de criterio para la Escala de Auto-compasión - Brasil. Una comparación del auto-compasión en practicantes budistas y católicos apoya la versión brasileña de la escala, así como evidencia diferencias religiosas en el tema. Participaron del estudio 59 católicos y 59 budistas, todos autodeclarados practicantes de su religión. Se administró una encuesta sociodemográfico y la Escala de Auto-compasión - Brasil. Los practicantes budistas presentaron puntuaciones más altas en auto-compasión $(M=4.45, S D=.51)$ que los católicos 
$(M=2.98, S D=.63): t(116)=13.78, p<.001(d=2.56)$. Fue detectada correlación positiva entre frecuencia de práctica y auto-compasión $(r=.39, p=.003)$. Futuros estudios pueden investigar la relación entre auto-compasión y practicantes de religiones neo-pentecostales, que crecen en número en Brasil.XC

Palabras-clave: auto-compasión; práctica religiosa; evidencia de validad; evaluación psicológica; escala

This study aims to provide criterion validity evidence for the Self-Compassion Scale Brazilian Version, available in Brazilian-Portuguese by Souza and Hutz (2016a, see also Souza, ÁvilaSouza \& Gauer, 2016). This is important in order to strengthen the scale for use in Brazil, providing further validity evidences that will secure the interpretations made from studies that may benefit by using the measure.

Evidences for criterion validity are valuable to ascertain the efficacy of the measure into predicting an external variable. This variable is fundamental for its strong relationship to the construct being tapped by the scale: the association between scale and the criterion under study offers evidence that helps predicting the how the construct will perform in certain events in given contexts (Primi, Muniz, \& Nunes, 2009; Reppold, Gurgel, \& Hutz, 2014). As the SelfCompassion Scale is proven to be useful for assessments in clinical contexts, providing as much as validity evidence possible supports its relevance and strength for use by psychologists.

The self-compassion construct adopted for the scale has deep Buddhist influences. In this sense, for the present investigation the main hypothesis is that self-compassion is different between Brazilian religious practitioners from Catholicism and Buddhism, with the latter presenting higher scores than the former.

Self-compassion ensembles a positive emotional attitude towards oneself; it is compassion turned inward. Even though Western Psychology has begun to investigate self-compassion recently, it is a core concept to the Buddhist Philosophy. Growing interest in studying self-compassion came from a tendency of integrating Buddhist constructs such as mindfulness in Western Psychology - both in science and practice (Neff, 2003a; Neff \& Lamb,
2009; Reppold \& Menezes, 2016). The extent of the mindfulness interventions in Psychology is noticeable within the so-called third wave of cognitive-behavior psychotherapies, which include the Acceptance and Commitment Therapy, the Mindfulness Based Therapy, and the Compassion Focused Therapy (Stevens, 2016).

The pioneer psychological study into the selfcompassion construct is credited to Kristin Neff (wwww.self-compassion.org), the first to propose an operational definition and construct measurement through the Self-Compassion Scale (Neff, 2003b). Since then, a considerable body of research on self-compassion has been developed, and published. Neff, Whittaker, and Karl (2017) show evidence that the measure is very sound.

In Brazil, studies on self-compassion started in Souza and Hutz (2013), with the cultural adaptation and construct validation procedures of the Escala de Autocompaixão (Souza \& Hutz, 2016a, b, c). The latest version of the scale is fully available for use in Brazilian-Portuguese as Escala de Autocompaixão - Versão Atualizada (Souza \& Hutz, 2016d, see also Souza et al., 2016). With adequate psychometric indices, this Brazilian version contributes to ongoing research in the country, as well as to the set of measures employed to, for example, health interventions assesses that include mindfulness, acceptance, and self-compassion (Souza \& Hutz, 2016a, d).

Self-compassion is composed of three interconnected elements: self-kindness versus self-judgment, common humanity versus isolation, and mindfulness versus over-identification. Although conceptually distinct and prone to be experienced differently at a phenomenological level, the elements interact to highlight and influence one another. Combined, they represent a self-compassionate frame of mind (Neff, 2016).

Self-kindness corresponds to the kind understanding and kind treatment of one-self, instead of judging one-self with harsh criticism. The common humanity is the understanding that lived negative experiences are a human experience (i.e., every human being experiences difficulties, suffering, errors, failures), instead of 
seeing one-self as chosen to suffer, isolating from other people. Mindfulness engenders a balanced awareness of thoughts and feelings that overcome the person in a given negative experience, instead of over-identifying with them - i.e., guiding all understanding of one-self, of everyone else, and of the world according to the lived suffering (Neff, 2003b, 2016).

It is important to note that self-compassion is a construct apart from self-pity. This presupposes taking distance from other people and being absorbed by owns' problems. In doing so, one forgets that other people may also be experiencing the same difficulty, or even worse (Neff, 2003b, 2016).

One of the studies conducted amidst the process of developing the original scale also compared self-compassion between college students and Buddhist practitioners from the United States (Neff, 2003b). Results showed significant differences on self-compassion, with a higher score in Buddhist practitioners $(p<.05)$. Moreover, Buddhist participants also presented significantly higher scores on the positive factors of the Self-Compassion Scale (self-kindness, common humanity, and mindfulness), and lower scores on the negative factors (self-judgment, isolation, and over-identification). Further analysis indicated a significant positive correlation between self-compassion and years of religious practice amongst the Buddhist practitioners ( $r=$ .35; $p<.05)$, i.e., a higher self-compassion scores goes along with duration of practice, precisely as hypothesized by Neff (2003b).

Another study that investigated the relation between religion and self-compassion used samples from Thailand, United States, and Taiwan (Neff, Pisitsungkagarn, \& Hsieh, 2008). The Asian cultures involved in the study bear different takes on how to treat one-self. In Thailand, the way of life is predominantly influenced by Buddhism; in Taiwan, there is a strong influence of Confucianism, considered as a philosophy, instead of a religion. Confucianism recognizes shame, judgment, and the threat of isolation as ways into self-enhancement. Therefore due to the low religious variability of the Thai sample, Neff et al., (2008) compared United States and Taiwan. Results indicated that religious orientation did not predict self-compassion among American participants, nor among the Taiwanese.

Notwithstanding the results, Neff et al. (2008) found significant differences for self-compassion among the three cultures $(p<.05)$. The highest self-compassion score was in the Thai sample (mean of 3.41), followed by the American sample ( $M=3.14)$, followed by the Taiwan sample ( $M=2.92)$. The analysis also indicated that the Thais showed higher levels of self-kindness and mindfulness, as well as lower levels in self-judgment, isolation, and over-identification, compared to Americans and Taiwanese (Neff et al., 2008).

These cross-cultural studies on selfcompassion are interesting for two reasons: first, there were no significant results for religious orientation in between countries; and second, the socio-demographical characteristics of the participants are varied religion-wise. Whilst the Taiwanese sample had $26 \%$ of Buddhists, $52 \%$ with no religion (probably influence from Confucianism), and $22 \%$ of other religions, the Thai sample was constituted by $98 \%$ of Buddhist volunteers; the American, of $76 \%$ Christians. Consequently, the high scores on self-compassion presented by the Thais suggested, alongside with the high prevalence of Buddhism in this country, that the relationship between self-compassion and religion needed further research.

There aren't many published investigations on self-compassion in Buddhist practitioners, even less in Brazil. It is relevant nevertheless to consider studies that tap into these aspects. Souza and Hutz (2016b) observed that selfdeclared Buddhists showed the highest score in self-compassion, compared to other religions. Nonetheless, religious groups varied greatly on sample size and were not approach whether the religion was indeed practiced.

As aforementioned, we expect to find higher self-compassion in Buddhist practitioners, compared to Catholic practitioners. According to the latest Brazilian census on religion, the 
majority of the population is Catholic - there are nearly 124 million Catholics (Instituto Brasileiro de Geografia e Estatística, 2010) (https://cidades. ibge.gov.br/brasil/pesquisa/23/22107). We also expect to find sex differences in self-compassion within groups, as indicated by previous studies (Neff, 2003b; Souza \& Hutz, 2016a, b, c).

Our main goal is to present criterion validity evidence for the Brazilian version of the SelfCompassion Scale. Consequently, we also shed light into the relationship between religious practice and self-compassion in a Brazilian sample.

\section{Method}

\section{Participants}

One-hundred and eighteen Brazilian adults participated on the study, with minimum age of 18 years-old and at least a high-school diploma. There were 59 Catholics (86\% female), age range 20-65 years $(M=32.9, S D=11.52)$ and 59 Buddhists (47.5\% female), age range 21-65 $(M=36.2, S D=$ 10.99), all self-declared their religion and status as a practitioner. Table 1 shows complementary socio-demographic characteristics of the samples.

Table 1 - Percentage of Socio-Demographic Characteristics per Religious Practice

\begin{tabular}{|c|c|c|}
\hline $\begin{array}{c}\text { Socio- } \\
\text { demographics }\end{array}$ & Catholics & Buddhists \\
\hline Female & 86 & 47.5 \\
\hline Male & 14 & 52.5 \\
\hline \multicolumn{3}{|l|}{ Marital status } \\
\hline Married & 29 & 36 \\
\hline Single & 39 & 29 \\
\hline With children & 17 & 30.5 \\
\hline University diploma & 85 & 54 \\
\hline Currently employed & 61 & 80 \\
\hline $\begin{array}{l}\text { Was under psycho- } \\
\text { therapy }\end{array}$ & 56 & 20 \\
\hline $\begin{array}{l}\text { Is currently under } \\
\text { psychotherapy }\end{array}$ & 24 & 0 \\
\hline Sample size & 59 & 59 \\
\hline
\end{tabular}

In addition to the data shown in Table 1 , the Buddhist sample was inquired about the number of times per week the person practices her/ his religion, and whether she/he belongs to a Buddhist community. Forty-nine (83\%) reported practicing Buddhism on a daily basis; $5 \%$ reported four times a week; $3.4 \%$ reported five; 3.4\% reported six times; and nearly $2 \%$ practices Buddhism twice a week. Fifty-seven (97\%) declared to be member of a Buddhist community. We also had data on the Buddhist sample about whether the practitioner ever took psychiatric medication, to which $8.5 \%$ answered yes; currently, 3.4\% takes psychiatric medication.

\section{Instruments}

Participants filled out a socio-demographic questionnaire and the Self-Compassion Scale in Brazilian-Portuguese, validated by Souza and Hutz (2016a, d; original from Neff, 2003b). The questionnaire required information such as religion and practice, sex, age, city of residence, marital status, employment status, university degree, and previous or current undertaking of psychotherapy. The Buddhist sample was also asked about frequency of practice per week, membership to a Buddhist community, and how long has been practicing Buddhism. Practitioners were self-declared as practitioner of the religion that she/he chose according to a short list offered in the socio-demographic questionnaire. Nearly all Buddhist participants belonged to a Buddhist community $(n=57)$.

The Self-Compassion Scale in BrazilianPortuguese measures the construct of selfcompassion through the interconnection of self-kindness versus self-judgment, isolation versus common humanity, and mindfulness versus over-identification. The scale has 26 items, with Cronbach's Alpha of .92; for each subscale, it was as follows: 77 for self-judgment, .76 for over-identification, .66 for common humanity, .79 for isolation, .81 for self-kindness, and .77 for mindfulness. Polychoric intercorrelations among the six factors ranged from .42 to .90. A higher order analysis (hierarchical model) showed the 
following indices: Results were $\chi 2=1407.494, d f=$ 293, $p<.0001, \mathrm{RMSEA}=.094$ (90\% Cl: .089-.099), $\mathrm{CFI}=.885, \mathrm{TLI}=.873$ (Souza \& Hutz, 2016a).

As there are significant differences between men and women in terms of self-compassion (Neff, 2003b), results must acknowledge this on interpreting data. Brazilian studies have shown that women has lower self-compassion than men (Souza \& Hutz, a, b), just as the same found in Neff's (2003b) north-American samples.

\section{Procedures}

Data collection. The Catholic practitioners were selected from a January 2016 data set where they acknowledged their religion and whether they practiced it. All had given written informed consent to participate on a study about selfknowledge. The Buddhist sample was obtained through invitations via email to enroll in an online psychology study answering a questionnaire sent after agreement to participate (data collected from August to December, 2015). All had to manifest, in the file attached with the study instruments, they accepted to participate in the study by indicating and " $x$ " at the end of the written informed consent sent also by email. Buddhist practitioners were located by personal contacts of the first and second authors of the present study and/ or invitations by email sent to various Buddhist centers along the country. After an adequate amount of Buddhists, and considering the time schedule for the study, the Catholic participants were selected from the available data set, pared to the Buddhist sample in terms of sex and age.

Data analysis. Descriptive statistics, Person correlations, and $t$ tests for independent samples were conducted, and well as Cohen's $d$ obtained for all comparisons. The minimum level of significance was established at .05, and all calculations used the SPSS software version 23.

\section{Ethical Considerations}

This study was approved by the ... Research Ethics Committee (approval number ...). All participants provided informed consent according to the ethics committee guidelines.

\section{Results}

As expected, Buddhist practitioners presented higher score in self-compassion than Catholic practitioners: $t(116)=13.78, p<.001$. The score in the Self-Compassion Scale for the Buddhists was $4.45(S D=.51)$, and for the Catholics was 2.98 (SD $=.63)$. Cohen's $d$ was 2.56 .

Given that sex differences are reported with Brazilian samples (Souza \& Hutz, a, b), we compared men and women from the Buddhist sample. There were not significant differences in self-compassion: $t(57)=-.85, p=.398$, Cohen's $d=.23$. The men's score was $4.51(S D=.53)$, and women's was 4.39 $(S D=.49)$. For information purposes, Catholic men and women also did not differ significantly in selfcompassion ( $p=.577, d=-.21$ ).

Concerning the association between duration of religious practice in years and selfcompassion in the Buddhist sample, there were no significant correlations $(r=.19, p=.162)$. There was, nonetheless, a significant positive correlation between frequency of practice per week and self-compassion: $r=.39, p=.003$. As a result, the more the Buddhist practices her/his religion, the higher is her/his self-compassion score. We decided to divide the Buddhists practitioners in two groups: Group 1 up to 6 times/week of practice $(n=8)$, self-compassion mean score = $3.87(S D=.73)$; and Group 2 daily practitioners ( $n$ = 49), self-compassion mean $=4.55(S D=.41)$. The difference between groups was significant: $t$ (55) $=-3.812, p<.001$. Cohen's $d$ was 1.14 .

Although not previously outlined, we performed other calculations, since the present study is mainly exploratory due to its topic. There were no significant correlations between age and the selfcompassion score within the Buddhist sample $(r$ $=-.06)$, neither within the Catholic sample $(r=.10)$.

\section{Discussion}

According to the rationale that supports the construct of self-compassion (Neff, 2003a, 2016) there is a strong Buddhist basis underneath the six elements that interact to generate the phenomenon. Taking this into account, it could be anticipated that Buddhist practitioners score 
higher in self-compassion than non-Buddhists. This in fact was observed by Neff (2003b), and some evidence along these lines was gathered by Souza and Hutz (2016b) in terms of religious affiliation, although without considering practice. The present study, hence, contributes with a further look into religion and self-compassion, adding practice to the equation.

The main purpose of the present study was to provide evidence of criterion validity for the Brazilian-Portuguese Version of the SelfCompassion Scale (Souza \& Hutz, 2016a, d). In order to carry out the investigation, we compared selfcompassion in Buddhist and Catholic practitioners. Results showed that Buddhist practitioners scored significantly higher than Catholic participants in self-compassion, with a large effect size detected. This favors adequate criterion validity for the Brazilian version of the scale.

Results also suggested that duration of practice, as well as frequency of practice per week, have their own influence on Buddhist practitioners. The longest the person practices Buddhist meditation, the higher is her/his self-compassion score. This result is also consistent with Neff's (2003b) study with Buddhist practitioners and duration of practice. Other evidence we provided for differentiating Buddhist practitioners was that the more frequent were the practices per week, the higher was their self-compassion score. This is interesting as, for instance, one of the elements of the construct of self-compassion - mindfulness - requires dedicated exercising of a meditative practice for one side, and the ability of keeping this skill functioning in the person's life (Reppold \& Menezes, 2016).

The gender comparisons did not show the significant differences in self-compassion as it would be expected, according to previous studies (Souza \& Hutz, 2016a, b). The one variable that is new to the present investigation is the practicing of the self-declared religion. It is possible that religious practice is beneficial to women, whom have been reported to show lower scores in self-compassion.

The limitation we would like to discuss about this study is sampling. Indeed we were not able to balance the amount of men and women for the Catholic practitioner's sample. In fact, the small frequency of male participants has been a constant concern in our studies on selfcompassion in Brazil. Previous investigations faced the same problem, and even an all female study was able to be carried out as a result of the large amount of female participants that came to fill out the Self-Compassion Scale (Souza \& Hutz, 2016c).

Taken the uneven distribution of males on the Catholic practitioner's sample, we sought literature on religious practice amongst Catholics. A qualitative inquiry on the relationship between gender and religion in Brazilians provides an insightful account on how religion, Catholicism included, is a female endeavor. According to Theije (2002), "the laic Catholic religious practice is stronger among women" (our translation, p.48) in Brazil, and there are "cultural ideas about psychological characteristics that are deep rooted in gender images in society" (our translation, p. 50). There are yet studies to be made with the aim of exploring this relationship between gender and other religions, such as Buddhism.

There are further investigations needed towards the continuation of generating evidences for validity processes for the Self-Compassion Scale - Brazilian Version. A future study with clinical samples might produce proper evidences. Yet to be diagnosed incoming patients with depression symptoms, or anxiety symptoms, would be expected to provide lower scores on self-compassion, according to previous studies (Diedrich, Burger, Kirchner, \& Berking, 2017). In addition, people with higher scores on life satisfaction and subjective well-being are also likely to show higher scores on self-compassion. Another avenue of research is the relationship between self-compassion and different religious practices. This could include neo-Pentecostal practitioners, which has been increasing in number in Brazil for the last two decades.

Along with the validity processes that may strengthen the interpretation of the SelfCompassion Scale - Brazilian Version, there is the importance of providing a reliable measure for the growing clinical interventions on mindfulness, 
acceptance, commitment, compassion, and other relevant aspects that have been under study in association with cognitive-behavior therapy. Of course, the successful self-compassion interventions (Arimitsu, 2016; Finlay-Jones, Kane, \& Rees, 2016) are also awaiting opportunities for application with Brazilian samples.

\section{References}

Arimitsu, K. (2016). The effects of a program to enhance self-compassion in Japanese individuals: a randomized controlled pilot study. Journal of Positive Psychology, 11(6), 559-571. Doi: https://doi.org/10.108 o/1743.9760.2016.1152593

Diedrich, A., Burger, J., Kirchner, M., \& Berking, M. (2017). Adaptive emotion regulation mediates the relationship between self-compassion and depression in individuals with unipolar depression. Psychology and Psychotherapy: Theory, Research and Practice, 90(3), 247-263. Doi: https://doi.org/10.1111/papt.12107

Finlay-Jones, A., Kane, R., \& Rees, C. (2016). Self-compassion online: a pilot study of an Internet-based self-compassion cultivation program for psychology trainees. Journal of Clinical Psychology, 73(7), 797-816. Doi: https://doi.org/10.1002/jclp.22375

Hutz, C. S. (Ed.) (2016). Avaliação em psicologia positiva: técnicas e medidas [Assessment in positive psychology: methods and measurements]. São Paulo: Hogrefe.

Instituto Brasileiro de Geografia e Estatística (2010). Censo. Amostra. Religião. [Census. Sample. Religion.] Retrieved from https://cidades.ibge.gov.br/brasil/ pesquisa/23/22107 Doi: inexistente.

Neff, K. (2003a). Self-compassion: an alternative conceptualization of a healthy attitude toward oneself. Self and Identity, 2(2), 85-101. Doi: http://psycnet.apa. org/doi/10.1080/15298860309032

Neff, K. (2003b). The development and validation of a scale to measure self-compassion. Self and Identity, 2(3), 223-250. Doi: http://psycnet.apa.org/ doi/10.1080/15298860309027

Neff, K. (2016). The Self-Compassion Scale is a valid and theoretically coherent measure of self-compassion. Mindfulness, 7(1), 264-274. Doi: http://dx.doi. org/10.1007/s12671-016-0560-6

Neff, K., \& Lamb, L. (2009). Self-compassion. In S. Lopez (Ed.), The Encyclopedia of Positive Psychology (pp. 864-867). Malden, MA: Wiley-Blackwell.

Neff, K., Pisitsungkagarn, K., \& Hsieh, Y. (2008). Self-compassion and self-construal in the United States, Thailand, and Taiwan. Journal of Cross-Cultural Psychology, 39, 267-285. Doi: http://dx.doi. org/10.1177/0022022108314544
Neff, K., Whittaker, T., \& Karl, A. (2017). Examining the factor structure of the Self- Compassion Scale in four distinct populations: is the use of a total scale score justified? Journal of Personality Assessment, 99(6), 596-607. Doi: https://doi.org/10.1080/00223891.2016.1269334

Primi, R., Muniz, M., \& Nunes, C. (2009). Definições contemporâneas de validade de testes psicológicos. In C. S. Hutz (Ed.), Avanços e polêmicas em avaliação psicológica [Advances and issues in psychological assessment] (pp. 243-265). São Paulo: Casa do Psicólogo.

Reppold, C., Gurgel, L., \& Hutz, C. (2014). O processo de construção de escalas psicométricas (technical note) [The process of construction of psychometric scales]. Avaliação Psicológica, 13(2), 307-310. Retrieved from http://pepsic. bvsalud.org/scielo.php? script=sci_arttext\&pi$\mathrm{d}=\mathrm{S} 1677=04712014000200018-\& \operatorname{lng}=\mathrm{pt} \& \mathrm{nrm}=$ iso \& tlng pt. Doi: inexistente.

Reppold, C., \& Menezes, C. (2016). Mindfulness. In C. S. Hutz (Ed.), Avaliação em psicologia positiva: técnicas e medidas [Assessment in positive psychology: techniques and measures] (pp. 45-74). São Paulo: Hogrefe.

Souza, L. K. de, Ávila-Souza, J., \& Gauer, G. (2016). Escala de Autocompaixão. In C. S. Hutz (Ed.), Avaliação em psicologia positiva: técnicas e medidas [Assessment in positive psychology: techniques and measures] (pp. 169-177). São Paulo: Hogrefe.

Souza, L. K. de, \& Hutz, C. H. (2013). Adaptação e validação da Escala de Autocompaixão e comparações com autoestima e autoeficácia (Relatório final de pesquisa) [Adaptation and validation of the Self-Compassion Scale and comparisons with self-esteem and self-efficacy (Research report)]. Porto Alegre, RS: Universidade Federal do Rio Grande do Sul, Post-Graduate Program in Psychology.

Souza, L. K. de, \& Hutz, C. S. (2016a). Adaptation of the Self-Compassion Scale for use in Brazil: evidences of construct validity. Trends in Psychology, 24(1), 159-172. Doi: http://dx.doi.org/10.9788/TP2016.1-11

Souza, L. K. de, \& Hutz, C. S. (2016b). Self-compassion in relation to self-esteem, self-efficacy and demographical aspects. Paidéia (Ribeirão Preto), 26(64), 181-188. Doi: http://dx.doi.org/10.1590/1982-43272664201604

Souza, L. K. de, \& Hutz, C. S. (2016c). A autocompaixão em mulheres e relações com autoestima, autoeficácia e aspectos sociodemográficos ISel$\mathrm{f}$-compassion in Brazilian women and relations with self-esteem, self-effcacy and demographic aspects]. Psico, 47(2), 89-98. Doi: http://dx.doi. org/10.15448/1980-8623.2016.2.21185

Souza, L. K. de, \& Hutz, C. S. (2016d). Escala de Autocompaixão - Como eu geralmente lido comigo em momentos dificeis. In C. S. Hutz (Ed.), Avaliação em psicologia positiva: técnicas e medidas [Assessment in positive psychology: techniques and measures] (pp.171-173). São Paulo: Hogrefe.

Stevens, B. (2016). Mindful self-compassion for chaplains and aged care workers. Journal of Religion, Spirituality \& Aging, 28(3), 255-263. Doi: https://doi.org $\underline{110.1080 / 15528030.2015 .1132490}$ 
Theije, M. de (2002). "São metade macho, metade fêmea": sobre a identidade de gênero dos homens católicos ["(They) are half male, half female": about gender identity of Catholic men]. Anthropológicas, 13(1), 47-56. Retrieved from: http://www.revista.ufpe. br/revistaanthropologicas/index.php/revista/article/view/4/16 Doi inexistente.

\section{Luciana Karine de Souza.}

Titulação Acadêmica: Doutorado.

Afiliação Institucional: Universidade Federal do Rio Grande do Sul.

\section{Caroline Tozzi Reppold.}

Titulação Acadêmica: Doutorado.

Afiliação Institucional: Universidade Federal de Ciências da Saúde de Porto Alegre

\section{Inajá Tavares.}

Titulação Acadêmica: Estudante de graduação.

Afiliação Institucional: Universidade Federal do Rio Grande do Sul.

\section{Claudio Simon Hutz.}

Titulação Acadêmica: PhD.

Afiliação Institucional: Universidade Federal do Rio Grande do Sul.

\section{Mailing address:}

Luciana Karine de Souza

Universidade Federal do Rio Grande do Sul

Rua Ramiro Barcelos, 2600, sala 101

Floresta 90035-003

Porto Alegre, RS, Brasil 